\title{
Perbandingan Perubahan Kadar Gula Darah Sebelum Pembedahan, 30 Menit dan 60 Menit Saat Pembedahan dengan Anestesi Umum dan Anestesi Spinal
}

\author{
${ }^{1}$ Muh. Alim Nur Yaqin \\ ${ }^{2}$ Harold F. Tambajong \\ ${ }^{2}$ Barry I. Kambey
}

\author{
${ }^{1}$ Program Studi Pendidikan Dokter Fakultas Kedokteran Universitas Sam Ratulangi Manado \\ ${ }^{2}$ Bagian Anestesiologi dan Terapi Intensif Fakultas Kedokteran Universitas Sam Ratulangi - \\ RSUP Prof. Dr. R. D. Kandou Manado \\ Email: muh.alimnuryaqin@yahoo.com
}

\begin{abstract}
Anesthesia and surgery could cause stress response within the body that affects blood glucose level. This study was aimed to compare blood glucose levels at 30 minutes and 60 minutes during surgery using general anesthesia and spinal anesthesia. This as an observational prospective analytical stdy with a cross-sectional design performed on 12 patients gathered through consecutive sampling that fulfilled inclusion and exclusion criteria. The patients were divided into 2 groups: those undergoing surgery with general anesthesia and those with spinal anesthesia. Measurement of blood glucose level was done 3 times, 2 hours before premedication induction, 30 minutes and 60 minutes during surgery. Data were analyzed statistically by using the Shapiro-Wilk test, the T-independent test, and the Mann Whitney. The results showed that there was no significant difference between blood glucose level at 30 minutes during surgery using general anesthesia and spinal anesthesia $(P=0.23)$, however, there was a significant difference between blood glucose level at 60 minutes during surgery using general anesthesia and spinal anesthesia $(P=0.03)$. Mean blood glucose level at30 minutes during surgery with general anesthesia was 103 $\mathrm{mg} / \mathrm{dl}$ and at 60 minutes during surgery was $116.7 \mathrm{mg} / \mathrm{dl}$, while mean blood glucose level at 30 minutes during surgery using spinal anesthesia was $93.50 \mathrm{mg} / \mathrm{dl}$ and at 60 minutes during surgery was $94.50 \mathrm{mg} / \mathrm{dl}$. Conclusion: There was a significant difference in blood glucose level between general anesthesia and spinal anesthesia at 60 minutes during surgery.
\end{abstract}

Keywords: stress response, blood glucose level, general anesthesia, spinal anesthesia

\begin{abstract}
Abstrak: Anestesi dan pembedahan dapat menyebabkan terjadinya suatu respon stres pada tubuh yang memengaruhi kadar gula darah. Penelitian ini bertujuan untuk membandingkan kadar gula darah 30 menit dan 60 menit saat pembedahan dengan anestesi umum dan anestesi spinal. Jenis penelitian ialah observasional analitik prospektif dengan desin potong lintang. Penelitian dilakukan terhadap 12 pasien yang didapatkan secara consecutive sampling dan memenuhi kriteria inklusi dan eksklusi, lalu dibagi menjadi 2 kelompok, yaitu kelompok yang menjalani pembedahan dengan anestesi umum dan kelompok yang menjalani menjalani pembedahan dengan anestesi spinal. Pengukuran kadar gula darah dilakukan 3 kali, yaitu 2 jam sebelum induksi premedikasi, serta 30 menit dan 60 menit saat pembedahan. Analisis statistik dilakukan dengan uji Shapiro-Wilk, uji TIndependen,, dan uji Mann Whitney. Hasil penelitian menunjukkan tidak terdapat perbedaan bermakna antara kadar gula darah 30 menit saat pembedahan dengan anestesi umum dan anestesi spinal $(P=0,23)$ sedangkan pada 60 menit saat pembedahan menunjukkan adanya perbedaan bermakna antara kadar gula darah 60 menit saat pembedahan dengan anestesi umum dan anestesi spinal $(P=0,03)$. Rerata kadar gula darah 30 menit saat pembedahan dengan anestesi umum yaitu $103 \mathrm{mg} / \mathrm{dl}$ dan 60 menit saat pembedahan yaitu $116,7 \mathrm{mg} / \mathrm{dl}$, sedangkan rerata kadar gula darah 30 menit saat pembedahan dengan anestesi spinal yaitu $93,50 \mathrm{mg} / \mathrm{dl}$ dan 60 menit saat pembedahan yaitu 94,50 mg/dl. Simpulan: Perubahan kadar gula darah yang bermakna antara anestesi umum dan anestesi spinal terjadi pada 60 menit saat pembedahan.
\end{abstract}

Kata kunci: respon stres, kadar gula darah, anestesi umum, anestesi spinal 
Anestesi dan pembedahan dapat menyebabkan terjadinya suatu respon stres pada tubuh. ${ }^{1}$ Respon stres ini terdiri dari tiga komponen utama, yaitu: 1) aktivasi sistem saraf simpatis; 2) respon endokrin dengan sekresi hormon hipofisis dan resistensi insulin; 3) perubahan imunologi dan hematologi. Respon stres tersebut menyebabkan peningkatan sekresi dari hormon anabolik dan katabolik yang mengakibatkan hipermetabolisme, serta percepatan sebagian besar dari reaksi biokimia. ${ }^{2}$

Salah satu respon stres yang terjadi pada tubuh akibat tindakan pembedahan ialah meningkatnya kadar gula darah. ${ }^{3} \mathrm{Hal}$ ini dipicu oleh adanya respon stres neuroendokrin selama dan setelah pembedahan. ${ }^{1,4}$ Respon stres tersebut ditandai dengan peningkatan kadar katekolamin, glukagon dan kortisol, yang berakibat pada mobilisasi simpanan karbohidrat dan protein, yang kemudian menyebabkan terjadinya peningkatan kadar gula darah. ${ }^{5}$

Anestesi umum merupakan suatu keadaan dimana pasien menerima obat agar mengalami amnesia, analgesia, paralisis otot, dan sedasi. ${ }^{6}$ Anestesi umum dimulai dengan pemberian obat intravena atau inhalasi anestesi yang mudah menguap dengan atau tanpa nitrit oksida. ${ }^{7}$ Teknik yang sering digunakan pada anestesi umum ialah anestesi inhalasi, dan teknik intravena sebagai alternatif. ${ }^{8}$ Umumnya, agen intravena digunakan untuk induksi dan agen inhalasi digunakan untuk pemeliharaan. ${ }^{9}$

Anestesi umum dapat meningkatkan konsentrasi adrenocorticotropic hormone (ACTH), kortisol, dan katekolamin. Hal ini terlihat pada penggunaan isofluran yang dapat meningkatkan konsentrasi ACTH dan katekolamin yang terjadi segera setelah tindakan pembedahan. Sevofluran-nitrit oksida juga menyebabkan peningkatan konsentrasi ACTH, kortisol dan katekolamin setelah dilakukan ekstubasi trakea. ${ }^{1}$ Seperti halnya anestesi inhalasi, anestesi umum dengan penggunaan agen intravena menyebabkan peningkatan katekolamin dan kortisol. Hal ini yang kemudian menyebabkan terjadinya peningkatan kadar gula darah. ${ }^{1}$
Anestesi spinal atau subarachnoid block adalah salah satu jenis anestesi regional yang dilakukan dengan cara menyuntikkan obat anestesi lokal ke dalam ruang subarachnoid melalui tindakan pungsi lumbal. ${ }^{10}$ Penyuntikan obat anestesi lokal tersebut langsung ke dalam cairan serebrospinal (CSF), di ruang subaraknoid. ${ }^{11}$ Lokasi penyuntikan anestesi spinal dilakukan di ruang subaraknoid pertengahan bawah lumbal, biasanya melalui sela L4L5 atau L3-L4. Obat anestesi lokal yang umumnya digunakan pada anestesi spinal ialah bupivakain. ${ }^{9}$

Penelitian Purnama et al. $^{12}$ yang dilakukan pada 43 pasien yang telah menjalani pembedahan dengan anestesi umum di RSUD Arifin Achmad Riau menunjukkan bahwa sebanyak 29 orang $(67,4 \%)$ mengalami peningkatan kadar gula darah pasca pembedahan dengan rerata $141,1 \mathrm{mg} / \mathrm{dl}$ sedangkan 14 pasien $(32,6 \%)$ dengan kadar gula darah pasca pembedahan normal. Rerata peningkatan kadar gula darah dari saat pembedahan ke pasca pembedahan sebesar $24,2 \%$ dan dari sebelum anestesi ke pasca pembedahan sebesar 41,6\%.

Rindarto dan Istanto $^{13}$ mendapatkan adanya pengaruh penambahan morfin dan klonidin pada bupivakain dosis rendah pada anestesi spinal terhadap kadar gula darah. Pada penelitian tersebut didapatkan bahwa pada kelompok perlakuan terjadi penurunan kadar gula darah sewaktu menjelang akhir pembedahan (menit ke-45), sedangkan pada kelompok kontrol justru terjadi kenaikan. Kadar gula darah sewaktu sebelum dilakukan anestesi spinal pada kedua kelompok tidak terdapat perbedaan bermakna $(P>0,05)$, yaitu $86,5 \pm 16 \mathrm{mg} / \mathrm{dl}$ pada kelompok perlakuan dan $86,1 \pm 20$ $\mathrm{mg} / \mathrm{dl}$ pada kelompok kontrol $(\mathrm{p}=0,94)$. Kadar gula darah sewaktu pada menit ke45 pada kedua kelompok ditemukan perbedaan bermakna $(P<0,05)$ yaitu $83,8 \pm 15 \mathrm{mg} / \mathrm{dl}$ pada kelompok perlakuan dibandingkan $100,9 \pm 28 \mathrm{mg} / \mathrm{dl}$ pada kelompok kontrol $(P=0,029)$.

Snezana et al. ${ }^{14}$ dalam penelitiannya mengenai pengaruh anestesi spinal dan 
anestesi umum terhadap respon metabolik, hormonal dan hemodinamik pada pasien bedah elektif, mendapatkan hasil pemeriksaan kadar gula darah yang lebih tinggi pada kelompok dengan anestesi umum dibandingkan kelompok dengan anestesi spinal $(P<0,05)$. Peningkatan kadar gula darah terjadi berkaitan dengan sekresi kortisol yang mencapai kadar puncak 30 menit setelah insisi dan mulai menurun 1 jam pasca pembedahan.

Penelitian ini bertujuan untuk membandingkan kadar gula darah 30 menit saat pembedahan dengan anestesi umum dan anestesi spinal dan kadar gula darah 60 menit saat pembedahan dengan anestesi umum dan anestesi spinal di RSUP Prof. Dr. R. D. Kandou Manado.

\section{METODE PENELITIAN}

Jenis penelitian ini ialah observasional analitik prospektif dengan desain potong lintang yang dilaksanakan di Instalasi Bedah Sentral (IBS) RSUP Prof. Dr. R. D. Kandou Manado periode Oktober- November 2017. Pemilihan sampel dilakukan dengan cara consecutive sampling karena keterbatasan waktu penelitian. Pada penelitian ini dilakukan pengukuran kadar gula darah sebanyak 3 kali, yaitu 2 jam sebelum induksi premedikasi, 30 menit dan 60 menit saat pembedahan.

\section{HASIL PENELITIAN}

Berdasarkan penelitian yang dilakukan di IBS RSUP Prof. Dr. R. D. Kandou Manado periode Oktober-November 2017, didapatkan 12 pasien memenuhi kriteria inklusi dan eksklusi, yang dibagi dalam 2 kelompok, yaitu, 6 pasien dengan anestesi umum dan 6 pasien dengan anestesi spinal.

\section{Karakteristik subjek penelitian}

Karakteristik subjek penelitian ini dibagi menjadi karakteristik umum dan karakteristik klinis, yang meliputi jenis kelamin, usia, indeks massa tubuh (IMT), jenis pembedahan dengan anestesi umum dan anestesi spinal.

Pada Tabel 1 dijelaskan karakteristik pasien yang mendapat anestesi umum menurut jenis kelamin, terdiri dari 1 pasien laki-laki $(16,7 \%)$ dan 5 pasien perempuan $(83,3 \%)$, sedangkan yang mendapat anestesi spinal terdiri dari 4 pasien laki-laki $(66,7 \%)$ dan 2 pasien perempuan $(33,3 \%)$.

Berdasarkan usia, didapatkan subjek terbanyak yang menggunakan anestesi umum pada rentang usia 36-45 tahun sebanyak 4 pasien $(66,7 \%)$, diikuti usia 2635 tahun dan 46-55 tahun masing-masing sebanyak 1 pasien $(16,7 \%)$. Subjek terbanyak yang menggunakan anestesi spinal pada rentang usia 18-25 tahun sebanyak 4 pasien $(66,7 \%)$, diikuti usia 36-45 tahun sebanyak 2 pasien $(33,3 \%)$. Berdasarkan IMT, kelompok pasien dengan anestesi umum sebanyak 4 pasien $(66,7 \%)$ dengan IMT 18,50-24,99 dan 2 pasien $(33,3 \%)$ dengan IMT 25,00-29,99. Pada kelompok pasien dengan anestesi spinal sebanyak 3 pasien (50\%) dengan IMT 18,50-24,99 dan 3 pasien (50\%) dengan IMT 25,00-29,99.

\begin{tabular}{ccc}
\hline Karakteristik & $\begin{array}{c}\text { Anestesia } \\
\text { umum } \\
\mathbf{n ( \% )}\end{array}$ & $\begin{array}{c}\text { Anestesia } \\
\text { spinal } \\
\mathbf{N}(\%)\end{array}$ \\
\hline Jenis kelamin & & \\
Laki-laki & $1(16,7 \%)$ & $4(66,7 \%)$ \\
Perempuan & $5(83,3 \%)$ & $2(33,3 \%)$ \\
Usia (tahun) & & $4(66,7 \%)$ \\
$18-25$ & 0 & 0 \\
$26-35$ & $1(16,7 \%)$ & \\
$36-45$ & $4(66,7 \%)$ & $2(33,3 \%)$ \\
$46-55$ & $1(16,7 \%)$ & 0 \\
IMT $\left(\mathrm{kg} / \mathrm{m}^{2}\right)$ & & \\
$18,50-24,99$ & $4(66,7 \%)$ & $3(50 \%)$ \\
$25,00-29,99$ & $2(33,3 \%)$ & $3(50 \%)$ \\
\hline
\end{tabular}

Pada Tabel 2 dijelaskan karakteristik subjek menurut jenis pembedahan. Jenis pembedahan dengan menggunakan anestesi umum yaitu bedah tulang sebanyak 2 pasien $(33,3 \%)$, kebidanan dan kandungan sebanyak 2 pasien $(33,3 \%)$, bedah digestif sebanyak 1 pasien $(16,7 \%)$ dan bedah urologi sebanyak 1 pasien $(16,7 \%)$. Pada anestesi spinal, jenis pembedahan dengan menggunakan anestesi spinal ialah bedah tulang sebanyak 4 pasien $(66,7 \%)$ diikuti kebidanan dan kandungan sebanyak 2 pasien $(33,3 \%)$. 
Tabel 2. Karakteristik klinis subjek penelitian

\begin{tabular}{ccc}
\hline Karakteristik & $\begin{array}{c}\text { Anestesia } \\
\text { umum } \\
\mathbf{n ( \% )}\end{array}$ & $\begin{array}{c}\text { Anestesia } \\
\text { spinal } \\
\mathbf{N}(\%)\end{array}$ \\
\hline Jenis pembedahan & & \\
Bedah tulang & $2(33,3 \%)$ & $4(66,7 \%)$ \\
Kebidanan \& & $2(33,3 \%)$ & $2(33,3 \%)$ \\
Kandungan & & \\
Bedah digestif & $1(16,7 \%)$ & 0 \\
Bedah urologi & $1(16,7 \%)$ & 0 \\
\hline
\end{tabular}

\section{Hasil pengukuran kadar gula darah}

Pada penelitian ini dilakukan 3 kali pengukuran kadar gula darah dari masingmasing pasien, yaitu 2 jam sebelum induksi premedikasi, 30 menit dan 60 menit saat pembedahan menggunakan alat GlucoDr. Kadar gula darah yang diukur yaitu kadar gula darah arteriol. Nilai normal kadar gula darah yaitu 70-125 mg/dl. Bila kadar gula darah $\geq 126 \mathrm{mg} / \mathrm{dl}$ dikatakan hiperglikemik dan bila kadar gula darah $<70 \mathrm{mg} / \mathrm{dl}$ termasuk kategori hipoglikemik.

Tabel 3 menunjukkan bahwa semua pasien pada kelompok anestesi umum yang terdiri dari 6 pasien $(100 \%)$ memiliki kadar gula darah 70-125 mg/dl (normal). Pada kelompok anestesi spinal semua pasien yang terdiri dari 6 pasien $(100 \%)$ memiliki kadar gula darah 70-125 mg/dl (normal).

Tabel 3. Kadar gula darah 2 jam sebelum pembedahan

\begin{tabular}{ccc}
\hline $\begin{array}{c}\text { Kadar gula } \\
\text { darah }\end{array}$ & $\begin{array}{c}\text { Anestesia } \\
\text { umum } \\
\mathbf{n = 1 6}\end{array}$ & $\begin{array}{c}\text { Anestesia } \\
\text { spinal } \\
\mathbf{n = 1 6}\end{array}$ \\
\hline$<70 \mathrm{mg} / \mathrm{dl}$ & 0 & 0 \\
$70-125 \mathrm{mg} / \mathrm{dl}$ & $6(100 \%)$ & $6(100 \%)$ \\
$\geq 126 \mathrm{mg} / \mathrm{dl}$ & 0 & 0 \\
Total & $6(100 \%)$ & $6(100 \%)$ \\
\hline
\end{tabular}

Tabel 4 menunjukkan bahwa semua pasien pada kelompok anestesi umum yang terdiri dari 6 pasien (100\%) memiliki kadar gula darah 70-125 mg/dl (normal). Pada kelompok anestesi spinal semua pasien yang terdiri dari 6 pasien $(100 \%)$ memiliki kadar gula darah 70-125 mg/dl (normal).

Tabel 5 menunjukkan bahwa terdapat 5 pasien $(83,3 \%)$ dalam kelompok anestesi umum yang memiliki kadar gula darah 70-
$125 \mathrm{mg} / \mathrm{dl}$ (normal), dan 1 pasien $(16,7 \%)$ yang memiliki kadar gula darah $\geq 126$ $\mathrm{mg} / \mathrm{dl}$ (hiperglikemik). Pada kelompok anestesi spinal semua pasien yang terdiri dari 6 pasien (100\%) memiliki kadar gula darah $70-125 \mathrm{mg} / \mathrm{dl}$ (normal).

Tabel 4. Kadar gula darah 30 menit saat pembedahan

\begin{tabular}{ccc}
\hline $\begin{array}{c}\text { Kadar gula } \\
\text { darah }\end{array}$ & $\begin{array}{c}\text { Anestesia } \\
\text { umum } \\
\mathbf{n = 1 6}\end{array}$ & $\begin{array}{c}\text { Anestesia } \\
\text { spinal } \\
\mathbf{n}=\mathbf{1 6}\end{array}$ \\
\hline$<70 \mathrm{mg} / \mathrm{dl}$ & 0 & 0 \\
$70-125 \mathrm{mg} / \mathrm{dl}$ & $6(100 \%)$ & $6(100 \%)$ \\
$\geq 126 \mathrm{mg} / \mathrm{dl}$ & 0 & 0 \\
Total & $6(100 \%)$ & $6(100 \%)$ \\
\hline
\end{tabular}

Tabel 5. Kadar gula darah 60 menit saat pembedahan

\begin{tabular}{ccc}
\hline $\begin{array}{c}\text { Kadar gula } \\
\text { darah }\end{array}$ & $\begin{array}{c}\text { Anestesia } \\
\text { umum } \\
\mathbf{n = 1 6}\end{array}$ & $\begin{array}{c}\text { Anestesia } \\
\text { spinal } \\
\mathbf{n = 1 6}\end{array}$ \\
\hline$<70 \mathrm{mg} / \mathrm{dl}$ & 0 & 0 \\
$70-125 \mathrm{mg} / \mathrm{dl}$ & $5(83,3 \%)$ & $6(100 \%)$ \\
$\geq 126 \mathrm{mg} / \mathrm{dl}$ & $1(16,7 \%)$ & 0 \\
Total & $6(100 \%)$ & $6(100 \%)$ \\
\hline
\end{tabular}

Perubahan kadar gula darah 2 jam sebelum pembedahan, 30 menit dan 60 menit saat pembedahan dengan anestesi umum dapat dilihat pada Gambar 1 dan dengan anestesi spinal pada Gambar 2.

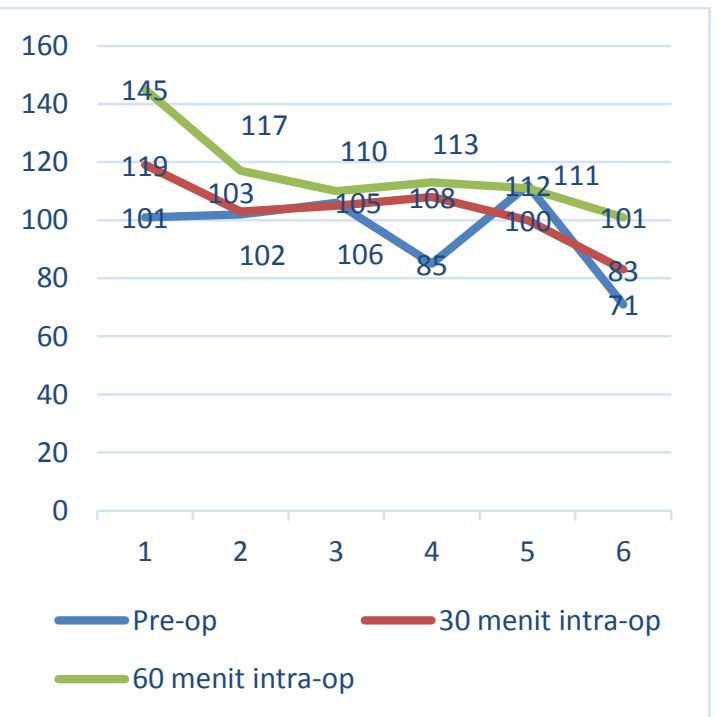

Gambar 1. Kadar gula darah 2 jam sebelum pembedahan, 30 menit dan 60 menit saat pembedahan dengan anestesi umum 
Yaqin, Tambajong, Kambey:Perbandingan perubahan kadar gula darah ...

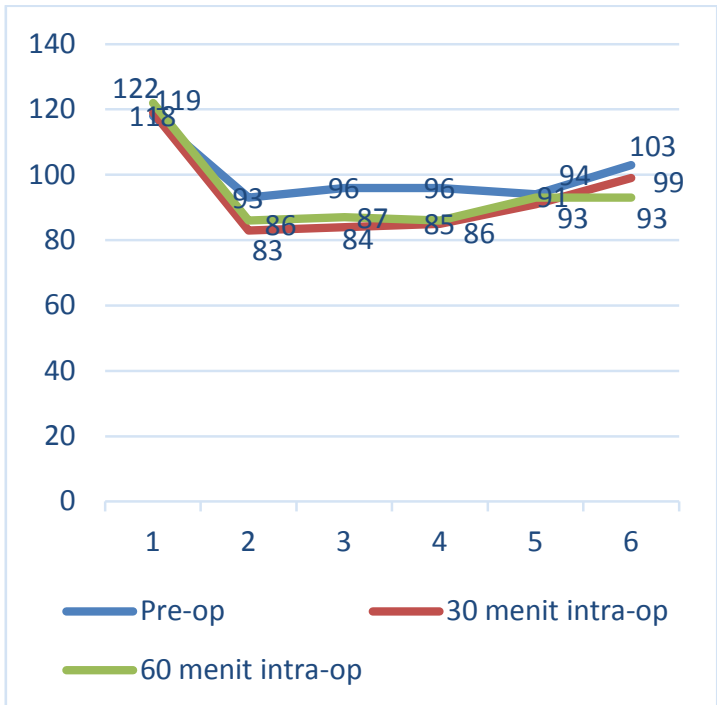

Gambar 2. Kadar gula darah 2 jam sebelum pembedahan, 30 menit dan 60 menit saat pembedahan dengan anestesi spinal

Tabel 6 menunjukkan 4 pasien $(66,7 \%)$ dalam kelompok anestesi umum mengalami peningkatan kadar gula darah dan 2 pasien $(33,3 \%)$ mengalami penurunan kadar gula darah dari 2 jam sebelum pembedahan ke 30 menit saat pembedahan. Pada anestesi spinal didapatkan 1 pasien $(16,7 \%)$ mengalami peningkatan kadar gula darah dan 5 pasien $(83,3 \%)$ mengalami penurunan kadar gula darah dari 2 jam sebelum pembedahan ke 30 menit saat pembedahan.

Tabel 6. Perubahan kadar gula darah dari 2 jam sebelum pembedahan ke 30 menit saat pembedahan

\begin{tabular}{ccc}
\hline $\begin{array}{c}\text { Perubahan } \\
\text { kadar gula } \\
\text { darah }\end{array}$ & $\begin{array}{c}\text { Anestesia } \\
\text { umum } \\
\mathbf{n = 1 6}\end{array}$ & $\begin{array}{c}\text { Anestesia } \\
\text { spinal } \\
\text { n=16 }\end{array}$ \\
\hline Meningkat & $4(66,7 \%)$ & $1(16,7 \%)$ \\
Menurun & $2(33,3 \%)$ & $5(83,3 \%)$ \\
Tidak berubah & 0 & 0 \\
Total & $6(100 \%)$ & $6(100 \%)$ \\
\hline
\end{tabular}

Tabel 7 menunjukkan 6 pasien $(100 \%)$ dalam kelompok anestesi umum mengalami peningkatan kadar gula darah dan tidak terdapat pasien yang mengalami penurunan kadar gula darah dari 30 menit saat pembedahan ke 60 menit saat pembedahan. Pada anestesi spinal didapatkan 5 pasien $(83,3 \%)$ yang mengalami peningkatan kadar gula darah dan 1 pasien $(16,7 \%)$ mengalami penurunan kadar gula darah dari 30 menit saat pembedahan ke 60 menit saat pembedahan.

Tabel 7. Perubahan kadar gula darah dari 30 menit ke 60 menit saat pembedahan

\begin{tabular}{ccc}
\hline $\begin{array}{c}\text { Perubahan } \\
\text { kadar gula } \\
\text { darah }\end{array}$ & $\begin{array}{c}\text { Anestesia } \\
\text { umum } \\
\mathbf{n = 1 6}\end{array}$ & $\begin{array}{c}\text { Anestesia } \\
\text { spinal } \\
\mathbf{n = 1 6}\end{array}$ \\
\hline Meningkat & $6(100 \%)$ & $5(83,3 \%)$ \\
Menurun & 0 & $1(16,7 \%)$ \\
Tidak berubah & 0 & 0 \\
Total & $6(100 \%)$ & $8(100 \%)$ \\
\hline
\end{tabular}

Tabel 8 menunjukkan bahwa rerata kadar gula darah sebelum pembedahan dengan anestesi umum yaitu 96,17 mg/dl, 30 menit saat pembedahan $103 \mathrm{mg} / \mathrm{dl}$, dan 60 menit saat pembedahan $116,7 \mathrm{mg} / \mathrm{dl}$, sedangkan rerata kadar gula darah sebelum pembedahan dengan anestesi spinal yaitu $100 \mathrm{mg} / \mathrm{dl}, 30$ menit saat pembedahan $93,50 \mathrm{mg} / \mathrm{dl}$, dan 60 menit saat pembedahan $94,50 \mathrm{mg} / \mathrm{dl}$.

Uji normalitas menggunakan uji Shapiro-Wilk untuk menentukan apakah data terdistribusi normal $(P>0,05)$ atau tidak $(P<0,05)$. Hasil yang didapatkan yaitu pada anestesi umum 2 jam sebelum pembedahan $P>0,05(P=0,372)$ yang menunjukkan bahwa data terdistribusi normal; 30 menit saat pembedahan $P>0,05(P=0,676)$ yang menunjukkan bahwa data terdistribusi normal; dan 60 menit saat pembedahan $P>$ $0,05(P=0,079)$ yang menunjukkan bahwa data terdistribusi normal. Pada anestesi spinal 2 jam sebelum pembedahan $P<0,05$ $(P=0,030)$ yang menunjukkan bahwa data tidak terdistribusi normal; 30 menit saat pembedahan $P>0,05 \quad(P=0,073)$ yang menunjukkan bahwa data terdistribusi normal, dan 60 menit saat pembedahan $P$ $<0,05(P=0,004)$ yang menunjukkan bahwa data tidak terdistribusi normal (Tabel 8).

Terdapat dua uji statistik yang digunakan yaitu uji Repeated ANOVA untuk data yang terdistribusi normal (anestesi umum) dan uji Friedman untuk data yang tidak terdistribusi normal (anestesi spinal) untuk mengetahui pengaruh antara dua variabel 
dalam hal ini perubahan kadar gula darah 2 sebelum pembedahan, 30 menit dan 60 menit saat pembedahan dengan anestesi umum dan anestesi spinal. Simpulan dari hasil uji statistik tersebut ialah anestesi umum lebih berpengaruh terhadap perubahan kadar gula darah dibandingkan dengan anestesi spinal. Hal ini dapat dibuktikan dengan uji statistik yang telah digunakan yaitu uji Repeated ANOVA untuk data pasien dengan anestesi umum, dimana nilai $P=0,05$ untuk anestesi umum. Pada anestesi spinal digunakan uji Friedman dengan nilai $P=0,06(P>0,05)$.

Tabel 9 menunjukkan terdapat perubahan kadar gula darah yang bermakna pada anestesi umum $(P<0,05)$. Perubahan ini dapat dilihat pada analisis post hoc dari 30 menit saat pembedahan ke 60 menit saat pembedahan dengan $P=0,03(P<0,05)$.

Tabel 10 menunjukkan perubahan kadar gula darah yang bermakna pada anestesi spinal $(P<0,05)$. Perubahan ini dapat dilihat pada analisis post hoc dari 2 jam sebelum pembedahan ke 30 menit saat pembedahan dengan $P=0,04(P<0,05)$.

Tabel 11 menjelaskan perbandingan antara anestesi umum dan anestesi spinal terhadap perubahan kadar gula darah yang tidak bermakna pada 30 menit saat pembedahan karena nilai $P=0,23 \quad(P$ $>0,05)$. Nilai $P$ dihitung berdasarkan uji tindependen karena data terdistribusi normal (Gambar 3).

Tabel 8. Data deskriptif 2 jam sebelum pembedahan, 30 menit dan 60 menit saat pembedahan dengan anestesi umum dan anestesi spinal

\begin{tabular}{ccccc}
\hline Jenis anestesi & Kadar gula darah & Mean & Sd. & $\begin{array}{c}\text { Uji normalitas } \\
\text { Shapiro-Wilk }\end{array}$ \\
\hline Umum & Pre-op & 96,17 & 15,25 & 0,37 \\
& 30 menit intra op & 103 & 11,78 & 0,67 \\
\multirow{2}{*}{ Spinal } & 60 menit intra op & 116,7 & 15,07 & 0,07 \\
& Pre-op & 100 & 9,48 & 0,03 \\
& 30 menit intra op & 93,50 & 13,80 & 0,07 \\
& 60 menit intra op & 94,50 & 13,86 & 0,004 \\
\hline
\end{tabular}

Tabel 9. Perubahan kadar gula darah sebelum pembedahan, 30 menit dan 60 menit saat pembedahan dengan anestesi umum

\begin{tabular}{ccc}
\hline Kadar gula darah & Rerata & $\boldsymbol{P}$ \\
\hline 2 jam sebelum pembedahan & 96,17 & 0,05 \\
30 menit pembedahan & 103 & \\
60 menit pembedahan & 116,7 & \\
\hline
\end{tabular}

Tabel 10. Perubahan kadar gula darah sebelum pembedahan, 30 menit dan 60 menit saat pembedahan dengan anestesi spinal

\begin{tabular}{ccc}
\hline Kadar gula darah & $\begin{array}{c}\text { Medium } \\
\text { (Minimum-Maksimum) }\end{array}$ & $\boldsymbol{P}$ \\
\hline 2 jam sebelum pembedahan & $96,00(93-118)$ & 0,06 \\
30 menit pembedahan & $88,00(83-119)$ & \\
60 menit pembedahan & $90,00(86-122)$ & \\
\hline
\end{tabular}

Tabel 11. Perbandingan anestesi umum dan anestesi spinal 30 menit saat pembedahan

\begin{tabular}{ccc}
\hline Jenis anestesi & Proses bedah & $\boldsymbol{P}$ \\
\hline Umum & $\begin{array}{l}30 \text { menit saat } \\
\text { pembedahan }\end{array}$ & 0,23 \\
Spinal & & \\
\hline
\end{tabular}


Tabel 12 menjelaskan perbandingan antara anestesi umum dan anestesi spinal terhadap perubahan kadar gula darah yang bermakna pada 60 menit saat pembedahan dengan $P=0,03 \quad(P<0,05)$ yang dihitung berdasarkan uji Mann Whitney karena data tidak terdistribusi normal (Gambar 4).

Tabel 12. Perbandingan anestesi umum dan anestesi spinal 60 menit saat pembedahan

\begin{tabular}{ccc}
\hline Jenis anestesi & Proses bedah & $\boldsymbol{P}$ \\
\hline Umum & 60 menit Saat & 0,03 \\
& Pembedahan & \\
Spinal & \\
\hline
\end{tabular}

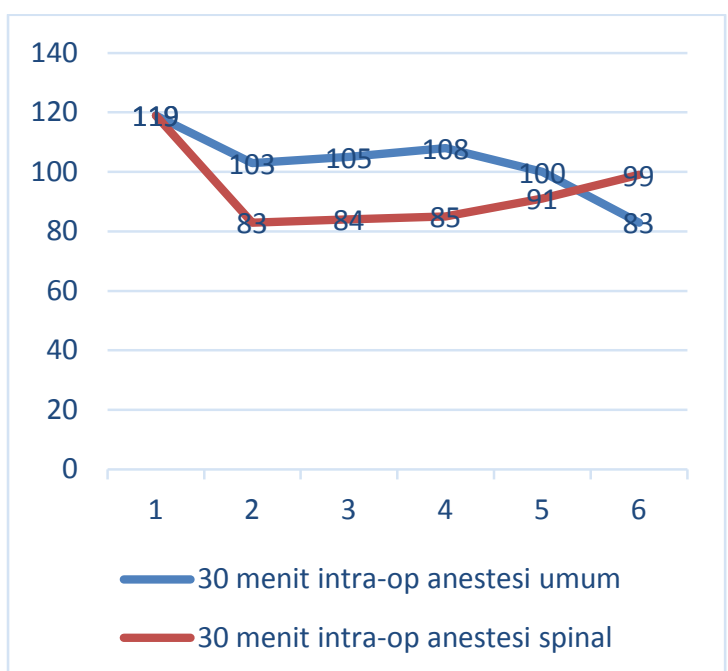

Gambar 3. Perbandingan kadar gula darah 30 menit saat pembedahan dengan anestesi umum dan anestesi spinal

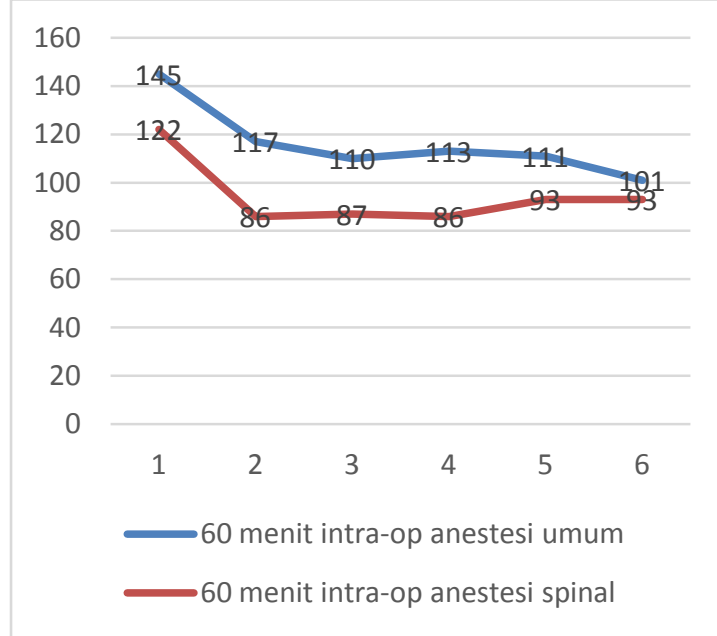

Gambar 4. Perbandingan kadar gula darah 60 menit saat pembedahan dengan anestesi umum dan anestesi spinal

\section{BAHASAN}

Tindakan pembedahan dapat menyebabkan terjadinya suatu respon stres pada tubuh. Respon stres tersebut dipengaruhi oleh tingkat kecemasan pasien terhadap pembedahan, efek metabolisme terhadap anestesi, dan prosedur pembedahan yang dijalani. Respon stres pada tubuh juga menyebabkan perubahan hormonal akibat dari tindakan pembedahan dan agen anestesi yang diberikan sehingga memicu sekresi dari hormon kortisol yang berpengaruh terhadap peningkatan kadar gula darah. Saat kortisol disekresi, terjadi peningkatan pengangkutan asam amino ke hati. Hal ini meningkatkan ketersediaan dari asam amino yang kemudian akan diubah menjadi glukosa. Di samping itu, juga terjadi peningkatan sekresi epinefrin yang dapat meningkatkan kadar gula darah. Epinefrin meningkatkan kadar gula darah dengan cara merangsang pemecahan glikogen oleh hati, mengurangi penyerapan glukosa oleh otot, dan menghambat pelepasan insulin oleh pankreas. ${ }^{15}$

Pada penelitian ini dapat dilihat perubahan kadar gula darah dari 2 jam sebelum pembedahan ke 30 menit saat pembedaham dan dari 30 menit saat pembedahan ke 60 menit saat pembedahan (Tabel 8). Frekuensi tertinggi kadar gula darah yang meningkat ialah pada anestesi umum dengan rerata $103 \mathrm{mg} / \mathrm{dl}$ pada menit ke 30 dan $116,7 \mathrm{mg} / \mathrm{dl}$ pada menit ke 60 saat pembedahan sedangkan rerata anestesi spinal ialah 93,50 mg/dl pada menit ke 30 dan 94,50 mg/dl pada menit ke 60 saat pembedahan. Jenis pembedahan yang dijalani pasien pada penelitian ini ialah ORIF, hysteroscopy + laparascopy + cystectomy, LAP-VC, cholecystectomy, THR, repair urethra, HT, HTSO serta pengangkatan implan dan revisi implan.

Peningkatan kadar gula darah yang terjadi saat pembedahan berkaitan dengan sekresi kortisol yang meningkat setelah insisi dan mulai menurun setelah pembedahan dilakukan. ${ }^{14}$

Berdasarkan Tabel 9 dan Tabel 10, anestesi umum lebih berpengaruh terhadap peningkatan kadar gula darah dibandingkan 
dengan anestesi spinal. Terdapat perubahan yang bermakna pada tiga kali pengukuran kadar gula darah untuk anestesi umum namun tidak ditemukan perubahan yang bermakna pada tiga kali pengukuran kadar gula darah untuk anestesi spinal. Berdasarkan uji statistik didapatkan nilai $P=0,05$ pada anestesi umum dan nilai $P>0,05$ pada anestesi spinal. Hasil penelitian ini didukung oleh penelitian Snezana et al. $^{14}$ yang menyatakan anestesi spinal lebih baik dalam menekan respon hiperglikemik dibandingkan dengan anestesi umum.

Berdasarkan Tabel 11 dan Tabel 12, tidak terdapat perubahan bermakna terhadap kadar gula darah 30 menit saat pembedahan dengan anestesi umum dan anestesi spinal, namun terdapat perubahan bermakna terhadap kadar gula darah 60 menit saat pembedahan dengan anestesi umum dan anestesi spinal. Berdasarkan uji statistik didapatkan nilai $P>0,05$ pada 30 menit saat pembedahan untuk anestesi umum dan anestesi spinal dan nilai $P<0,05$ pada 60 menit saat pembedahan untuk anestesi umum dan anestesi spinal.

Anestesi umum tidak menghilangkan respon stres sepenuhnya. Hal ini disebabkan karena agen-agen intravena dan inhalasi pada anestesi umum dalam dosis yang normal memiliki pengaruh sedikit terhadap fungsi endokrin dan metabolik, sehingga terjadi peningkatan sekresi kortisol dan menyebabkan peningkatan kadar gula darah, sedangkan anestesi spinal berpengaruh langsung terhadap fungsi endokrin dan metabolik dengan menghambat secara total sinyal nosiseptif untuk mencapai sistem saraf pusat. Penghambatan pada fungsi endokrin dan metabolik terjadi pada jalur aferen dan eferen. Jalur aferen ini yang akan melepaskan kortisol melalui jalur eferen oleh ACTH. Blokade saraf pada T4S5 selama pembedahan abdomen bagian bawah dapat mencegah respon hormon kortisol terhadap efek hiperglikemik. ${ }^{4}$

Terdapat penelitian lain yang menunjukkan hasil berbeda mengenai perubahan kadar gula darah 30 menit saat pembedahan antara anestesi umum dan anestesi spinal. Penelitian yang dilakukan oleh Snezana et al. ${ }^{9}$ menunjukkan perbedaan bermakna pada perubahan kadar gula darah 30 menit saat pembedahan antara anestesi umum dan anestesi spinal.

Salah satu hal yang dapat menimbulkan perbedaan hasil penelitian yaitu jumlah sampel yang sedikit. Pada penelitian ini jumlah sampel tidak mencapai target awal disebabkan keterbatasan waktu penelitian yang dilakukan.

\section{SIMPULAN}

Berdasarkan hasil penelitian ini dapat disimpulkan bahwa tidak terdapat perbedaan bermakna pada perubahan kadar gula darah 30 menit saat pembedahan antara anestesi umum dan anestesi spinal.

Terdapat perbedaan bermakna pada perubahan kadar gula darah 60 menit saat pembedahan antara anetesi umum dan anestesi spinal.

\section{SARAN}

Disarankan untuk penelitian lanjut yang melibatkan hubungan antara jenis kelamin, usia, indeks massa tubuh dan jenis pembedahan dengan perubahan kadar gula darah saat pembedahan yang menggunakan salah jenis anestesi (anestesi umum atau anestesi spinal).

Disarankan untuk penelitian lanjut mengenai membandingkan kadar gula darah antara anestesi umum dan anetesi spinal terhadap satu jenis pembedahan.

\section{DAFTAR PUSTAKA}

1. Weissman C. Nutrition and metabolic control. In: Miller RD, Eriksson LI, Fleisher LA, Wiener-Kronish JP, editors. Miller's Anesthesia Vol 2 (7th ed). New York: Churchill Livingstone, 2010; p.2940-3.

2. Cevasco M, Ashley S, Cooper Z. Physiologic response to surgery. In: Mc Kean SC, Ross JJ, Dressler DD, Brotman DJ, Ginsber JS, editors. Principles and Practice Of Hospital Medicine. China: McGraw Hill Companies, 2012.

3. Hall GM. Perioperative glucose control. IARS. 2010 annual event meeting of the International Anesthesia Research Society. 2010 March 20-23. Honolulu, 
Hawaii, p. 24-7.

4. Singh M. Stress response and anaesthesia altering: the peri and post-operative management. Indian J Anaesth. 2003; 47(6):427-34.

5. Butterworth JF, Mackey DC, Wasnick JD. Morgan \& Mikhail's Clinical Anesthesiology (5th ed). US: McGraw Hill Companies, 2013; p. 691-701.

6. Medscape. General Anesthesia. [cited 2017 Aug 7]. Available from: http:// emedicine.medscape.com/article/12715 43-overview

7. Stoelting RK, Miller RD. Basics of Anesthesia (5th ed). China: Churchill Livingstone, 2007; p.179.

8. Dobson M. Penuntun Praktis Anestesi. Jakarta: EGC, 2012; p. 53.

9. Keat S, Bate ST, Bown A, Lanham S. Anaesthesia on the Move [Senapathi TGA trans]. UK: Hodder Arnold, 2012; p. 100-10.

10. Mangku G, Senapathi TGA. Buku Ajar Ilmu Anestesia dan Reanimasi. Jakarta Barat, Penerbit Inddeks, 2010; p. 24.

11. Gwinnut CL. Catatan Kuliah Anestesi Klinis (3rd ed) . Jakarta: EGC, 2014; p. 73.

12. Purnama N, Sony, Fridayenti. Gambaran kadar gula darah perioperative pada pasien bedah elektif menggunakan anestesi umum di RSUD Arifin Achmad Provinsi Riau [Skripsi]. Riau: Fakultas Kedokteran Universitas Riau; 2013.

13. Rindarto, Istanto $W$. Pengaruh penambahan morfin dan klonidin pada Bupivakain dosis rendah pada anestesi spinal untuk bedah sesar ditinjau dari perubahan hemodinamik dan kadar glukosa darah. Medica Hospitalia. 2013;2(1):6-13.

14. Milosavlijevic SB, Pavlovic AP, Trpkovic SV, Ilic AN, Sekulic AD. Influence of spinal and general anesthesia on the metabolic, hormonal, and hemodynamic response in elective surgical patients. NCBI. 2014;20:183340.

15. Topp DS. The nondiabetic's blood glucose tolerance to the stress of surgery. Journal of the American Association of Nurse Anesthetics. 1985:338-41. 